\title{
Isolation and structural analysis of the laccase gene from the lignin- degrading fungus Phlebia radiata
}

\author{
Markku Saloheimo, ${ }^{*}$ Marja-Leena Niku-Paavola and Jonathan K. C. Knowles $\dagger$
}

VTT Biotechnical Laboratory, Tietotie 2, SF-02150 Espoo, Finland

(Received 30 November 1990; revised 4 February 1991; accepted 28 February 1991)

\begin{abstract}
We have isolated and characterized a gene coding for the laccase of the lignin-degrading fungus Phlebia radiata. The gene has nine introns and recognizable fungal promoter elements. Sequences homologous to the consensus eukaryotic heat-shock regulatory element can be found in the promoter. RNA hybridization results indicate that this gene is regulated at the transcriptional level. The derived laccase amino acid sequence shows homology to plant ascorbate oxidases, suggesting that the basic structure of the laccase is similar to the three-fold repeated $\beta$-barrel of the ascorbate oxidases. Potential copper ligands and a residue carrying the prosthetic group pyrroloquinoline quinone (PQQ) in the laccase protein can be identified by homology. The intron/exon structure of the laccase gene suggests that this protein could have evolved by exon shuffling.
\end{abstract}

\section{Introduction}

Lignin degradation mediated by white-rot fungi is thought to be a non-specific oxidative process (for a review see Kirk \& Farrel, 1987). The initial step in this process is the removal of an electron from a subunit of lignin by a ligninolytic enzyme. These fungal enzymes can be either peroxidases that use $\mathrm{H}_{2} \mathrm{O}_{2}$ as their electron acceptor or oxidases (laccases) that use $\mathrm{O}_{2}$ for this purpose. The ability of laccases to oxidize lignin model compounds with phenolic hydroxyl groups suggests that these enzymes have a role in lignin degradation (Ishihara, 1980). The molecular genetics of the ligninolytic peroxidases has been widely studied (e.g. Tien \& Tu, 1987; Brown et al., 1988; Pribnow et al., 1989; Saloheimo et al., 1989) and one report on laccase sequences from a ligninolytic fungus, Coriolus hirsutus, has been published (Kojima et al., 1990).

A number of different lignin-degrading enzymes of the white-rot fungus Phlebia radiata have been isolated and characterized (Niku-Paavola et al., 1988; Karhunen et $a l ., 1990 a)$. One of these is a laccase (EC 1.10.3.2) with

† Present address: Glaxo Institute of Molecular Biology SA, Route des Acacias 46, 1211 Geneva 24, Switzerland.

Abbreviations: AOase, ascorbate oxidase; HSE, heat shock element; ORF, open reading frame; PCR, polymerase chain reaction; PKDAO, porcine kidney diamine oxidase; $P Q Q$, pyrroloquinoline quinone.

The nucleotide sequence data reported in this paper have been submitted to EMBL Data Library/GenBank and have been assigned the accession number X52134. a molecular mass of $64 \mathrm{kDa}$. Recently this enzyme has been suggested to contain two copper atoms, one in type 1 and one in type 2 configurations and the prosthetic group pyrroloquinoline quinone (PQQ) (Karhunen et al., $1990 \mathrm{~b}$ ). Most of the laccases described so far have four copper atoms, including also the type 3 binuclear copper pair (Malkin \& Malmström, 1970). Moreover, this Phlebia enzyme is the first laccase for which the presence of PQQ has been suggested.

In this work we describe the isolation and characterization of the chromosomal gene and cDNA coding for the laccase of $P$. radiata. The regulation of the gene was studied by RNA hybridization. The sequences of the gene and the putative laccase protein are compared with other known multicopper oxidase sequences and the structure and evolution of the enzyme are discussed.

\section{Methods}

Strains and vectors. Phlebia radiata ATCC 64658 was grown as described by Saloheimo et al. (1989) for RNA and DNA isolations. A chromosomal gene library from $P$. radiata was constructed in the $\lambda$ EMBL3 vector using the host strain Escherichia coli NM 538 (Frischauf et al., 1983). A $P$. radiata cDNA library was constructed in $\lambda$ gt 11 and was grown in the $E$. coli host Y1090 (Young \& Davis, 1983). Bluescript $\mathrm{M} 13+$ (Vector Cloning Systems) and the host strain E. coli DH5 alpha (BRL) were used in plasmid constructions.

Isolation and sequencing of the laccase gene. P. radiata DNA was isolated by the method of Raeder \& Broda (1985) and used in construction of a chromosomal gene library in $\lambda$ EMBL3 (Kaiser \& Murray, 1983). Phlebia laccase protein was purified and antibodies 
CGACGCAGCGACCGCT'TACCATAACCTGCGAACGGGCGGCAAACGTAATCGGTCGAACGGCGGTCAGACCTGGCCCAACAGGCCGGGATG GACAGCTTTGCGAAATTGCCTCGGTGGTATGAACGTTAGAGAACACAGACAGGGTATAAAAGCCCTATACCAGGTCGCATTGAAAACCTC AGCCCCCGGTCTCAAAGGATCCTCTCCAGTCTCCAAGCAATATGCACACTTTCCTTCGCTCCACGGCACTCGTTGTGGCAGGCCTGTCT

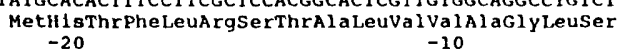

GCCCGCGCCCTTGCCAGCATTGGGCCCGTTACCGACTTTCACATCGTCAACGCCGCCGTCTCTCCCGATGGTTTCTCTCGCCAGGCTGTC

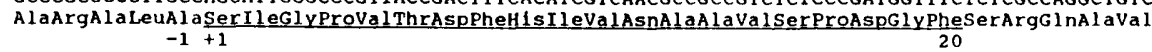

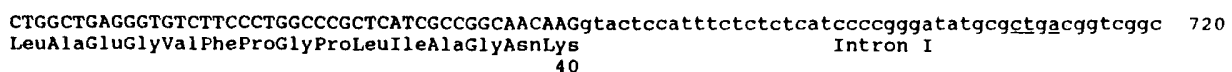
40

aCagGGCGACAATTTCCAGATCAATGTCATTGACGAATTGACCAACGCAACTATGTTGAAGACTACCACTATCgTCagt CaCt tgCCaC

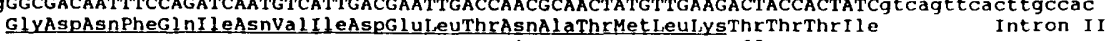

tccegtgttctcactctgąattaatcgtctttggtagCACTGGCATGGCTTCTTCCAGCACGGTACAAACTGGGCTGATGGACCGGCA UISTrPHIsGlyPhePheGInUISGl YThrAsnTrPAl aAspGIYProAla

TTTATCAATCAATGCCCCATTGCGTCTGGTGACTCGTTCCTGTACAACTTCCAGGTGCCCGACCAAGCTGgtatgtcccagtttcctgttg 990 PheIleAsnGInCys ProIleAlaSerGlyAspSerPheLeuTyrAsnPheGInValProAspglnalag Intron III 100

ttggataataccagcatçttáattattatgatacagGTACCTTCTGGTATCACAGCCATCTCTCCACGCAGTACTGTGACGGTCTTCGC lyThrPheTrPTyrH isSerH IsLeuSerThrGInTYRCYSAspGly LeuArg
GGACCTITCG'LAGTGTACGATCCTGCTGACCCGTACCTTGACCAGTACGACGTCGA'TGATGgtacgcaagaggcatteattgttttcgCtt 1170 GlyProPheValValTyrAspProAlaAspProTyrLeuAspGInTyrAspValAspAspA Intron IV 140

a ta tattgaaccctgctcagACAGCACTGTTATCACTTTGGCGGACTGGTATCACACCGCCGCGAGATTGGGGAGCCCTTTCCCgtaagt 1260 spSerThrVal I leThrLeUAl aAspTrPTYrH IsThrA IaAlaArgLeUGlySerProPhePr

GGCTGCCCGGTCTCTGATCTTGCTGTCATCTCGGTTACTAAAGGCAAACGgtatgtcgatcgttcagtagcatgttagtatctaacattt 1440 GlyCysProvalserAspLeuAlaValI IeSerValThrLysGlyLYsAr
180

tctgccttccagCTACCGTTTCCGCCTGGTTTCCATCTCTTGCGATTCATTCTTCACATTTAGCATCGATGGGCACAGTCTGAACGTCATT 1531 gTyrArgPheArgLeUValSerIl eSerCysAspSerPhePh:ThrPheSerIl eAspGI YHisSerLeuAsnVal I le
200

GAGGTTGATGCTACCAACCACCAGCCGTTGACCGTCGACGAGCTCACTATTTATGCAGGCCAGCGCTACTCCTTCATCgtaagtttcaa 1620

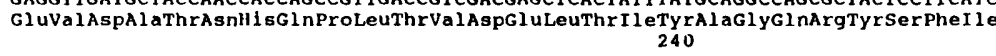

gtgtaacgtgactcagactgaaggttattgatgacatttgttacttagCTCACGGCCGACCAAGACGTCGATAACTACTGGATCCGAGCA 1710 Intron VII LeuThrAlaAspGInAspValAspAsnTYrTrPI leArgAla

AACCCCGGTATTGGCATCACCACAGGCTTTGCGGGCGGTATCAACTCTGCTATTCTTCGTTATGATGGTGCCGACGTGGTCGAGCCTACA 1800

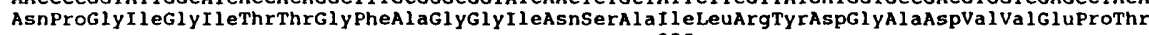
280

ACTACTCAGGCGACAAGTCCCGTTGTGCTGAGCGAGTCGAACTTGGCCCCACTGACCAACGCTGCTGCTgtcagtcttatcttttgtgta 1890 ACTACTCAGGCGACAAGTCCGTTGTCTGAGCGGTCGACTTGGCCCACTGACCAACGCTGCTGCTgtcagtcttatcttttgtgta
ThrThrGlnAlaThrSerProValVal LeuSerGluSerAsnLeuAlaProLeuThrAsnAlaAlaAla In VII 300

ttgctttgcttgcgtctagccggtagatctttagCCTGGTCTCCCGGAGGTTGGCGGTGTCGACCTTGCCCTCAACTTCAACCTGACCTTC 1981 ProGlyLeuProgluValglyGlyValAspleuAlaLeuAsnPheAsnLeuThrPhe

gtgagtaccetggctgaatcgagcggatatttgttgaacgcagggttgtgcagGATGGCCCCTCCCTAAAATCCAAATCAACGGAGTC Intron IX AspGlyProserLeuLys PheGInIleAsnglyVal 340

ACCTTCGTTCCGCCCACCGTGCCCGTTCTTCTCCAAATCCTCAGTGGTGCCCAGTCGGCTGCAGACCTACTGCCATCCGGAAGCGTGTAC Thr PheVal ProProThrVal Proval LeuLeuglnI leLeuSerGlyAlaglnSerA laAlaAspLeuLeuProSerGlyServalTy 360

GCGCTGCCTTCGAACGCGACCATCGAGCTGAGTCTGCCCGCCGGCGCACTGGGCGGCCCGCACCCCTTCCACTTGCACGGCCACACCTTC

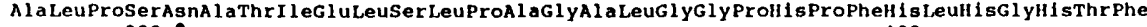
380 .

AGCGTCGTCCGTCCCGCTGGCTCCACGACGTACAACTATGTCAACCCCGTCCAGCGTGACGTCGTGAGCATTGGAAACACCGGCGACAAC 2340

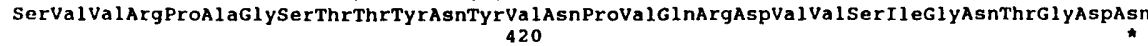

GTCACAATCCGCTTCGATACTAACAACCCGGGCCCGTGGTTCCTCCATTGCCACATTGACTGGCATCTCGAGGCTGCTTTGCCGTTGTCT 2430 ValThrI leArgPheAspThrAsnAsnProGlyProTrpPheLeUH isCysH IsI leAspTrpHisLeuGluAlaAlaLeuProLeuSer 440

TCGCTGAGGACATCCCTGACGTTGCGTCCATTAACCCTGTCCCCCAGGACTGGTCCAACCTGTGCCCTATCTACAACGCTCTGGACGCAT 2520 SerLeuArgThrSerLeuThrLLeuArgProLeuThrLeuSerProArgThrGl y ProThrCysAlaLeuSerThrThrLeuTrpThrHis
480

CTGATCACTAGCGGATTCGCATCAATCATACAGTGGATGATGGGTGGTAACGGACTATTTGCACCACATGCTCTTTCATTTCTCGGGTCG 2610

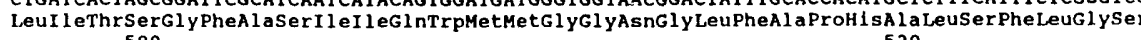
500 poly A CAGTAAGGATAAATTCGTAACCTACAACTCTTCTTGTAGAGTAACAACCAACGGAATGTCGTAAGAAATTGTTTCTACGATTATACTGGC 2700 Gln

ATGGGAACGAACACTTCAACGTAAGGAATGGTATTGAAGTCTGGGGCAATTGTTGGCGACATGTAGTGGGAACTGTTGATGGatGGGCC 2790 AGACGTTGAGAAGCCCATTTCATATCATCCTGTGACGAAGGACT 2834 
were prepared against it as described by Niku-Paavola et al. (1988). A Phlebia cDNA gene library was screened with antibodies as described by Huynh et al. (1983). cDNA synthesis and DNA amplification were done according to Frohman et al. (1988). DNA sequencing was done with synthetic oligonucleotide primers and plasmid DNA templates using modified T7 DNA polymerase (USB). Protein sequencing was done as described by Saloheimo et al. (1989).

$R N A$ hybridization. $P$. radiata RNA was isolated as described by Saloheimo et al. (1989). The Hybond N nylon membrane (Amersham) was used in blotting and hybridization according to the manufacturer's instructions.

\section{Results}

\section{Isolation and sequence of the P. radiata laccase gene}

A $P$. radiata cDNA library constructed in $\lambda$ gt 11 (Saloheimo et al., 1989) was screened with polyclonal antibodies against the laccase of the fungus. A positively reacting clone with an insert of about $800 \mathrm{bp}$ was isolated. The cDNA library was further screened with the insert of this clone as a probe. The longest cDNA isolated in the second round of screening was about $1.5 \mathrm{~kb}$, which could not contain the whole coding region of the gene. A genomic library was therefore constructed from $P$. radiata DNA in the vector $\lambda$ EMBL3. This library was screened by plaque hybridization with the isolated cDNA as a probe. The chromosomal laccase gene was isolated and transferred from a $\lambda$ clone into Bluescript $\mathrm{M} 13$ + as a $1.6 \mathrm{~kb}$ SacI and a $2.0 \mathrm{~kb}$ Asp 718 fragment. The $5^{\prime}$ end of the gene not present in the isolated cDNA clones was sequenced from the chromosomal plasmid constructions.

The $5^{\prime}$ end of the laccase cDNA was then cloned using the polymerase chain reaction (PCR). Two oligonucleotides based on chromosomal gene sequence (Fig. 1) were used in a PCR reaction. The template in this reaction was cDNA synthesized from Phlebia mRNA isolated from mycelium induced for production of ligninolytic enzymes. A DNA fragment comprising the 5 ' end of the cDNA was obtained, cloned into Bluescript M13+ plasmid and sequenced. Comparing this sequence with the corresponding region in the chromosomal laccase gene revealed no differences except for the three introns that are in this area.

The region sequenced from the chromosomal and cDNA copies of the gene spans over $2834 \mathrm{bp}$ of DNA (Fig. 1), which includes about $500 \mathrm{bp}$ of the promoter region. A putative TATA box TATAAAA is found
77 bp and a putative CAAT element 253 bp upstream from the translation start site.

A gene encoding a manganese-dependent peroxidase of Phanerochaete chrysosporium has been found to contain heat-shock regulatory elements (HSE) in its promoter and shown to be regulated by heat shock (Godfrey et al., 1990). Three sequences homologous to the eukaryotic consensus HSEs (C--GAA--TTC--G; Pelham, 1982) can be found in the promoter of the Phlebia laccase gene (boxed in Fig. 1). These sequences show a homology of $6 / 8,5 / 8$ and $6 / 8$ to the consensus, although in the sequence farthest upstream there is only one base between the GAA- and TTC-like elements. Furthermore, the HSE-like element farthest downstream in the laccase promoter shows an identity of 10/14 base pairs to the most proximal HSE-like element of the Mnperoxidase promoter of Phanerochaete (Godfrey et al., 1990). Whether the Phlebia laccase gene is regulated by heat shock remains to be determined.

Sequences of two peptides digested from the laccase of Phlebia radiata with lysyl endopeptidase can be identified in the putative amino acid sequence derived from the gene studied (Fig. 1). Thus the gene isolated very probably codes for the Phlebia laccase described earlier (Niku-Paavola et al., 1988). One of the peptide sequences is preceded in the ORF of the gene by 21 amino acids, reminiscent of a typical signal sequence with a positively charged $\mathrm{N}$-terminus followed by a hydrophobic region. For this reason it is likely that this amino acid sequence is derived from the $\mathrm{N}$-terminal peptide of the protein.

The molecular mass of the mature laccase protein derived from the ORF of the gene is $56440 \mathrm{Da}$, and that of the isolated laccase is $64 \mathrm{kDa}$ (Niku-Paavola et al., $1988)$. The difference $(11.8 \%)$ is probably due to glycosylation. The putative laccase has four potential $\mathrm{N}$ glycosylation sites (Asn-Xxx-Ser/Thr), at positions 54, 330,381 and 436. The region containing the first $\mathrm{N}$ glycosylation site was included in one of the two peptide sequences determined from the protein and, interestingly, Asn54 did not give an identifiable signal. This suggests that this glycosylation site is used in vivo.

\section{RNA hybridization}

$P$. radiata was grown in a medium with a low nitrogen content, to induce the production of ligninolytic enzymes (Saloheimo et al., 1989) and mycelial samples were collected after 1, 2 and $3 \mathrm{~d}$ of growth. RNA was isolated

Fig. 1. Nucleotide sequence of the $P$. radiata laccase gene with the putative laccase amino acid sequence. Putative TATA and CAAT boxes are underlined in the promoter region of the gene. HSE-like sequences are boxed, with underlining of the bases homologous to the consensus (C--GAA--TTC--G). Introns are shown in lower case. Putative splicing signals are underlined in the introns. Sequences of oligonucleotides used in the PCR amplification of the $5^{\prime}$ end of the laccase cDNA are overlined. Peptide sequences obtained from the Phlebia laccase protein are underlined in the putative amino acid sequence. Potential $N$-glycosylation sites are shown by asterisks. The polyadenylation site observed is shown in the $3^{\prime}$ flanking area. 


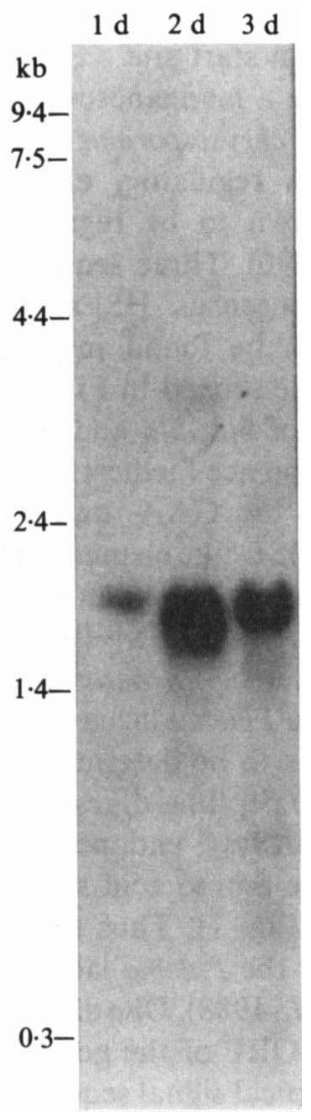

Fig. 2. Northern hybridization of $P$. radiata RNA isolated from mycelium induced for production of ligninolytic enzymes. Mycelium was grown for 1,2 or $3 \mathrm{~d}$ as indicated at the top. RNA samples of $2 \mu \mathrm{g}$ were used in each case. RNA Ladder (BRL) fragments were used as size standards.

and Northern hybridization with the laccase cDNA as a probe was performed from these samples (Fig. 2). Equal loading of RNA to the hybridized gel lanes was controlled by staining a similarly loaded RNA gel with acridine orange (data not shown). A single transcript of about $1.9 \mathrm{~kb}$ is seen at each timepoint. This is in good agreement with the size of the isolated laccase gene.

Production of laccase activity by $P$. radiata in bioreactor cultivations similar to that used for the RNA isolations has been described (Kantelinen et al., 1989). Typically, the laccase activity starts to appear after day 1 , reaching its peak value on day 3 , after which it starts to decrease. The laccase mRNA levels (Fig. 2.) are consistent with the enzyme activity profile. Some laccase mRNA is transcribed on day 1 . After $2 \mathrm{~d}$ of growth, as the enzyme activity is still increasing, the mRNA level is highest. On the third day the mRNA level has started to decrease. The above suggests that the regulation of the laccase gene of Phlebia occurs to at least some extent at the level of transcription. This has also been shown for two other types of ligninolytic enzymes, the lignin peroxidase (Tien \& $\mathrm{Tu}, 1987$ ) and Mn-peroxidase (Pribnow et al., 1989) of the white-rot fungus Phanerochaete chrysosporium, and is generally the case for regulated fungal genes.

\section{Discussion}

Homology of the P. radiata laccase to other multicopper oxidases

The primary structures of six multicopper oxidases, human ceruloplasmin (Ortel et al., 1984), laccases of Neurospora crassa (Germann et al., 1988), Aspergillus nidulans (Aramayo \& Timberlake, 1990) and Coriolus hirsutus (Kojima et al., 1990) and the ascorbate oxidases (AOase) of cucumber (Ohkawa et al., 1989) and pumpkin (Esaka et al., 1990) have been reported previously. Most importantly, the crystal structure of the zucchini AOase has been published (Messerschmidt et al., 1989). It is a dimeric protein with a molecular mass of $140 \mathrm{kDa}$. Each subunit of the dimer is divided into three domains with a similar polypeptide folding of a $\beta$-barrel type. The domains are thus clearly related to the small coppercontaining blue proteins such as plastocyanins of plants (Colman et al., 1978) and azurins of bacteria (Adman et al., 1978). Therefore it would seem probable that the AOase has evolved through a triplication of an ancestral gene coding for a small copper protein (Messerschmidt $e t$ al., 1989).

The primary structure of the zucchini AOase has not been published. However, the known amino acid sequence of the AOase from cucumber is about $90 \%$ homologous to the zucchini enzyme (Ohkawa et al.,1989; Messerschmidt et al., 1989). Assuming that the structure of cucumber AOase is very similar to that of the zucchini enzyme we have compared the fungal laccases with the cucumber sequence. The Neurospora, Phlebia and Coriolus laccases are about $30 \%$ homologous to this AOase. The laccases of the ligninolytic fungi, $P$. radiata and $C$. hirsutus, show an identity of $63 \%$. Interestingly, the homology of these two laccases to the Neurospora laccase is no greater than it is to the AOase. In the A. nidulans laccase, homology to the other oxidases can be detected only in the active-site regions.

The alignment of Phlebia and Coriolus laccase and the cucumber AOase sequences is shown in Fig. 3. The AOase has previously been aligned with Neurospora crassa laccase by another group (Messerschmidt \& Huber, 1990). Our alignment is different from the previous one in the middle domain of AOase and shows greater homology between AOase and Phlebia laccase. Alignment of the proteins by hydrophobic cluster analysis (Gaboriaud et al., 1987) gives support to the 


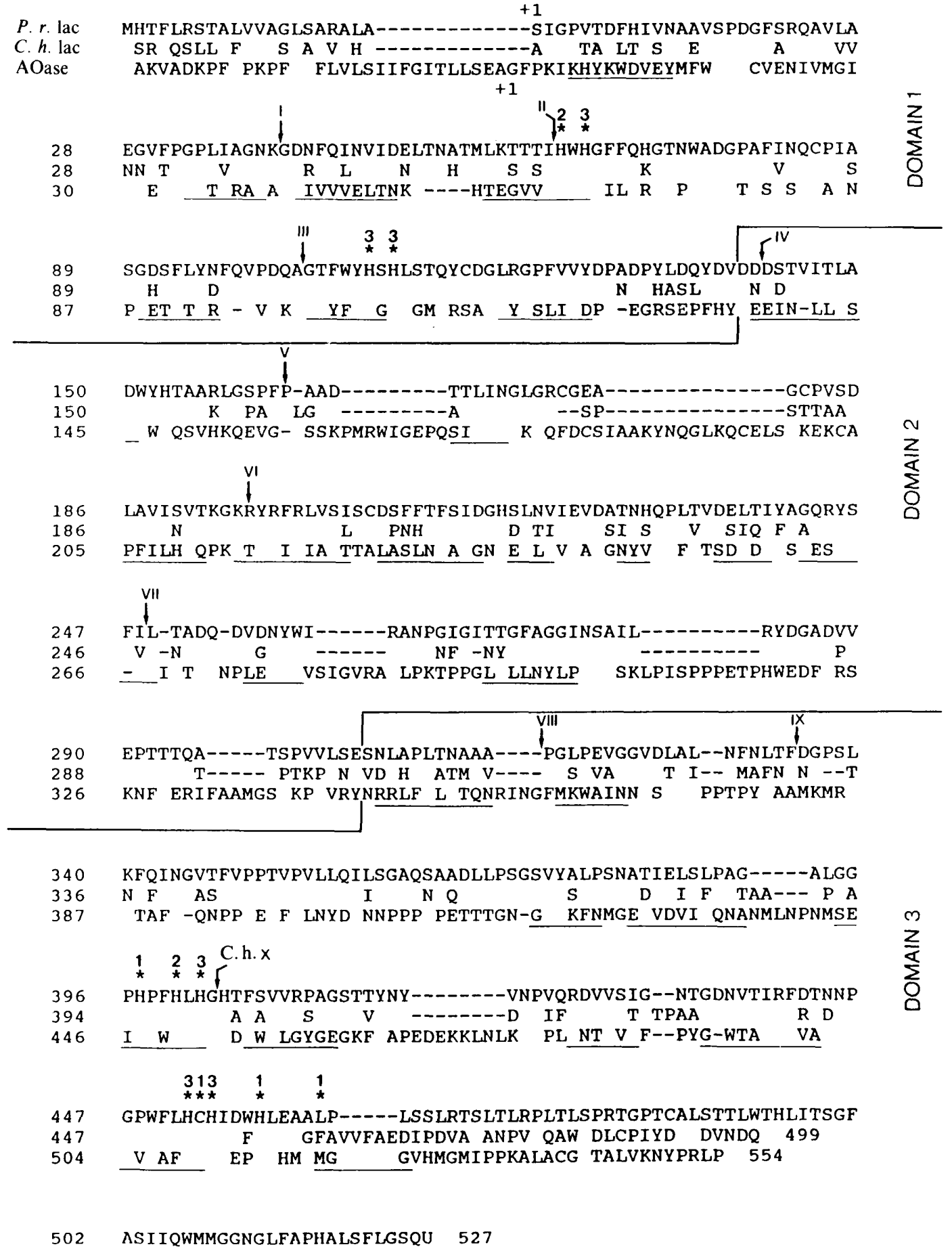

Fig. 3. Alignment of the amino acid sequences of Phlebia radiata laccase ( $P$. r. lac), Coriolus hirsutus laccase ( $C$. $h$. lac) and the ascorbate oxidase of cucumber (AOase). Conserved amino acids have not been marked, and gaps are indicated by -. The domain structure of the cucumber AOase is indicated. Amino acids working as copper ligands in the active site of AOase are shown by asterisks and numbers indicating the copper configuration which these ligands are parts of. $\beta$-Strands forming the basic fold of AOase are shown by underlining of the AOase sequence. Locations of introns in the laccase genes are shown by arrows with the intron numbering by Roman numerals $(C . h . \mathrm{X}$ refers to the tenth intron of the Coriolus laccase genes). 
alignment presented here in regions of low homology (B. Henrissat \& M. Saloheimo, unpublished). As the laccase sequences can be aligned with the AOase throughout their whole lengths, it is likely that the basic architecture of their polypeptide folding is similar to that of the AOase.

The three repetitive structural domains and the locations of the $\beta$-strands forming-the basic fold of the cucumber AOase are shown in the alignment in Fig. 3. The homology of the three proteins compared is highest in the $\mathrm{N}$-terminal domain 1 and lowest in the middle domain 2. Moreover, the proteins are best conserved in the central parts of each domain. This is not unexpected, since the active-site regions of the AOase are located in the central parts of domains 1 and 3 . Domain 2 contains many deletions in the laccases when compared to the AOase of cucumber. An extension of about 30 amino acids in the C-terminus of the Phlebia laccase is revealed by the alignment.

The active site of AOase contains four copper atoms, one type 1 or blue, one type 2 or normal, and two type 3 or binuclear (Messerschmidt et al., 1989). The type 1 copper configuration is clearly homologous to the only copper atom in the small copper proteins (Colman et al., 1978; Adman et al., 1978). The ligands for this copper (two His, Met and Cys) that lie in the C-terminal domain 3 are conserved in the fungal laccases with one exception: Met 519 of the AOase is replaced by a leucine or a phenylalanine. The type 2 and type 3 copper atoms are in close proximity, forming a trinuclear complex. The type 2 copper has two histidines and the two type 3 coppers have six histidines serving as their ligands (Messerschmidt et al., 1989). All of these amino acids are conserved in all of the fungal laccases.

The $P$. radiata laccase has been suggested to contain two copper atoms per protein molecule, in type 1 and type 2 configurations as indicated by electron paramagnetic resonance (Karhunen et al., 1990b). As stated above, all the six ligands for type 3 copper atoms are conserved in the sequence of this laccase and also their surroundings are rather well conserved. Thus it would seem probable that the geometry of the active site of the $P$. radiata laccase is different from AOase in such a way that it is unable to bind the type 3 copper atoms.

\section{Possible binding site of the prosthetic group $P Q Q$}

Recently, it has been suggested that the laccase of $P$. radiata is a quinoprotein, in that it contains PQQ as its prosthetic group (Karhunen et al., 1990b). PQQ is a twoelectron-transferring group found in many oxidoreductases of microbial, plant and animal origin. It is bound covalently to its apoenzyme in eukaryotic quinoproteins (Duine, 1988). van der Meer et al. $(1988,1989)$ have

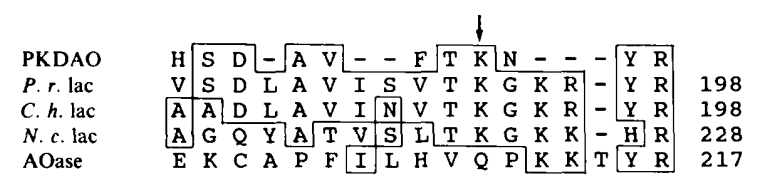

Fig 4. Alignment of the sequence of the peptide carrying $P Q Q$ in porcine kidney diamine oxidase (PKDAO) with homologous sequences in Phlebia radiata, Coriolus hirsutus and Neurospora crassa laccases and cucumber AOase. Homologous amino acids are boxed. The lysine suggested to be bonded to PQQ in PKDAO is indicated by an arrow. Amino acid numbering is shown.

$$
\text { N. c. lac } 31 \text { N T G }
$$

Fig. 5. Alignment of the Neurospora crassa laccase and cucumber AOase protein sequences (Messerschmidt \& Huber, 1990) in the region containing the only intron of the laccase gene (Germann et al., 1988). Identical amino acids are boxed with a solid line and similar ones with a broken line. The laccase gene intron position is shown by an arrow. The first $\beta$-strand of AOase is represented by a dashed line. Amino acid numbering is indicated.

suggested that PQQ forms an amide bond with a lysyl residue in the apoprotein of porcine kidney diamine oxidase (PKDAO). They have also determined a short segment of amino acid sequence around the lysine proposed to carry PQQ.

Amino acid stretches homologous to the PQQcarrying peptide of PKDAO can be found in the laccases of Phlebia radiata, Coriolus hirsutus and Neurospora crassa (Fig. 4). It is interesting to note that the highest homology is found between PKDAO and the laccases of Phlebia and Coriolus (8 identical residues out of 11). The above suggests that the amino acid carrying PQQ in $P$. radiata laccase could be Lys193. The prosthetic $\xi$ roup would thus be situated in the middle domain 2 of he enzyme (Fig. 3). The PQQ-carrying lysine of PKDAO is conserved in $N$. crassa laccase, but not in cucumber AOase. In addition, this region of AOase shows rather low homology to the other proteins. To our knowledge PQQ analysis has not been performed for Coriolus or Neurospora laccases. However, their different copper content (four atoms per enzyme molecule) from the Phlebia laccase suggests a different active site structure from the Phlebia protein. PQQ was not found when the structure of the zucchini AOase was solved (Messerschmidt et al., 1989).

Janes et al. (1990) recently showed that bovine serum amine oxidiase, which has been suggested to be a quinoprotein, has 6-hydroxydopa instead of PQQ as its cofactor. They suggested that this could also be true for other mammalian copper oxidases that have been characterized as quinoproteins. Whether this concerns PKDAO or Phlebia laccase remains to be demonstrated. 
The intron/exon structure of the $P$. radiata laccase gene

The protein-coding region of the $P$. radiata laccase gene is interrupted by nine introns. This number is relatively large for a fungal gene (Ballance, 1986). However, the lignin peroxidase genes sequenced from Phanerochaete chrysosporium (e.g. Brown et al., 1988) have eight introns and in the lignin peroxidase gene of Phlebia radiata the number is at least eight (M. Saloheimo, unpublished). The Coriolus hirsutus laccase gene contains ten introns (Kojima et al., 1990). The positions of nine of these are conserved in the Phlebia laccase gene without a single base change when the alignment presented in Fig. 3 is used as a guideline. The most proximal intron of the Coriolus gene has no counterpart in the Phlebia sequence. As is typical for the genes of filamentous fungi (Ballance, 1986), introns in the Phlebia laccase gene are short, 47$59 \mathrm{bp}$ in length. Sequences at the intron/exon junctions and splicing signals (Fig. 1) follow the fungal consensus (Ballance, 1986).

In genes coding for proteins with the $\alpha \hat{\beta}$-barrel type of folding, introns are non-randomly positioned in regions between the repeated $\alpha$-helix- $\beta$-strand structures of the protein (e.g. Lonberg \& Gilbert, 1985; Buisson et al., 1987). Therefore it has been suggested that these proteins could have evolved by duplications of exons that code for structural domains of the protein (Lonberg \& Gilbert, 1985). We have indicated the locations of introns in the Phlebia and Coriolus laccase genes and the locations of $\beta$ strands forming the basic fold of AOase in Fig. 3 . Provided that the $\beta$-strands of the laccase are in the positions suggested by the alignment in this figure, then it appears that the introns are non-randomly placed in the laccase gene. Five out of the nine introns conserved in the Phlebia and Coriolus laccase genes (I, III, IV, VI and VIII) are at or only a few nucleotides away from positions corresponding to $\mathrm{N}$-termini of $\beta$-strands in the AOase structure. The tenth intron of the Coriolus genes is also in a similar position. In addition, alignment of the region containing the only intron of the laccase gene of Neurospora crassa with AOase reveals that this intron is adjacent to an $\mathrm{N}$-terminus of a $\beta$-strand in the AOase structure (Fig. 5). The above would suggest that the laccases of ligninolytic fungi could have evolved by a mechanism similar to that suggested for the $\alpha \beta$-barrel proteins. Moreover, intron IV in the Phlebia laccase gene and the intron of the Neurospora laccase gene are near locations corresponding to $\mathrm{N}$-termini of domains 1 and 2 of the AOase. Thus, these introns might have been involved when the $\beta$-barrel was triplicated to form the present AOase.

In this paper we have presented hypotheses concerning the active site structure of the $P$. radiata laccase. Verifying any of these hypotheses will require exper- imental data gained by site-directed mutagenesis of the laccase gene and heterologous production of mutant laccase-proteins. Therefore, we are presently studying the expression of the Phlebia laccase gene in another fungus, Trichoderma reesei.

We wish to thank A. Kantelinen for Phlebia cultivations, S. Keränen, M. Penttilä, B. Henrissat and T. T. Teeri for valuable discussions, $\mathbf{M}$. Bauman and $\mathbf{M}$. Saraste for peptide sequencing and $\mathbf{H}$. Lehtonen and $\mathrm{K}$. Berg for excellent technical assistance. The work was supported by the Neste Oy Foundation.

\section{References}

Adman, E. T., Stenkamp, R. E., Sieker, L. C. \& Jensen, L. H. (1978). A crystallographic model for azurin at $3 \AA$ resolution. Journal of Molecular Biology 123, 35-47.

aramayo, R. \& Timberlake, W. E. (1990). Sequence and molecular structure of the Aspergillus nidulans yA (laccase I) gene. Nucleic Acids Research 18, 3415.

Ballance, D. J. (1986). Sequences important for gene expression in filamentous fungi. Yeast 2, 229-236.

Brown, A., Sims, P. F. G., Raeder, U. \& Broda, P. (1988). Multiple ligninase-related genes from Phanerochaete chrysosporium. Gene 73, 77-85.

Buisson, G., Duee, E., Haser, R. \& Payan, F. (1987). Three dimensional structure of porcine pancreatic $\alpha$-amylase at $2.9 \AA$ resolution. Role of calcium in structure and activity. EMBO Journal 6, 3909-3916.

Colman, P. M., Freeman, H. C., Guss, J. M., Murata, M., Norris, V. A., Ramshaw, J. A. M. \& VenkatapPa, M. P. (1978). X-ray crystal structure analysis of plastocyanin at $2.7 \AA$ resolution. Nature, London 272, 319-324.

DuINE, J. A. (1988). PQQ and quinoproteins: an important novel field in enzymology. In PQQ and Quinoproteins, pp. 351-360. Edited by J. A. Jongejan \& J. A. Duine. Dordrecht, Boston \& London: Kluver Academic Publishers.

Esaka, M., Hattori, T., Fujisawa, K., Sakajo, S. \& Asahi, T. (1990). Molecular cloning and nucleotide sequence of full-length cDNA for ascorbate oxidase from cultured pumpkin cells. European Journal of Biochemistry 191, 537-541.

Frischauf, A.-M., Lehrach, H., Poutska, A. \& Murray, N. (1983). Lambda replacement vectors carrying polylinker sequences. Journal of Molecular Biology 170, 827-842.

Frohman, M. A., Dush, M. K. \& Martin, G. R. (1988). Rapid production of full-lenth cDNAs from rare transcripts: amplification using a single gene-specific oligonucleotide primer. Proceedings of the National Academy of Sciences of the United States of America 85, 8998-9002.

Gaboriaud, C., Bissery, V., Benchetrit, T. \& Mornon, J. P. (1987). Hydrophobic cluster analysis: an efficient new way to compare and analyse amino acid sequences. FEBS Letters 224, 149-155.

GermanN, U. A., Muller, G., Hunziker, F. E. \& Lerch, K. (1988) Characterization of two allelic forms of Neurospora crassa laccase. Journal of Biological Chemistry 263, 885-896.

Godfrey, B. J., Mayfield, M. B., Brown, J. A. \& Gold, M. H. (1990). Characterization of a gene encoding a magnanese peroxidase from Phanerochaete chrysosporium. Gene 93, 119-124.

Huynh, T. V., Young, R. A. \& Davis, R. W. (1983). Construction and screening of cDNA libraries in $\gamma \mathrm{gt} 10$ and $\gamma \mathrm{gt} 11$. In DNA Cloning. A Practical Approach, pp. 49-78. Edited by D. M. Glover. Oxford: IRL Press.

IsHIHARA, T. (1980). The role of laccase in lignin degradation. In Lignin Degradation: Microbiology, Chemistry and Potential Applications, vol. 2, pp. 17-31. Edited by T. K. Kirk, T. Higuchi \& H. Chang. Boca Raton: CRC Press. 
Janes, S. M., Mu, D., Wemmer, D., Smith, A. J., Kaur, S., Maltby, D., Burlingame, A. L. \& Klinman, J. P. (1990). A new redox cofactor in eukaryotic enzymes: 6-hydroxydopa at the active site of bovine serum amine oxidase. Science 248, 981-987.

Kaiser, K. \& Murray, N. E. (1985). The use of phage lambda replacement vectors in the construction of representative genomic DNA libraries: In DNA Cloning. A Practical Approach, pp. 1-47. Edited by D. M. Glover. Oxford: IRL Press.

Kantelinen, A., HatakKa, A. \& ViIKari, L. (1989). Production of lignin peroxidase and laccase by Phlebia radiata. Applied Microbiology and Biotechnology 31, 234-239.

Karhunen, E., Kantelinen, A. \& Niku-Paavola, M.-L. (1990a). Mn-dependent peroxidase from the lignin-degrading white-rot fungus Phlebia radiata. Archives in Biochemistry and Biophysics 279, 25-31.

Karhunen, E., Niku-Paavola, M.-L., Viikari, L. Haltia, T., van DER MEER, R. A. \& DUINE, J. A. (1990 $b$ ). A novel combination of prosthetic groups in a fungal laccase; PQQ and two copper atoms. FEBS Letters 267, 6-8.

KIRK, T. K. \& FARrell, R. L. (1987). Enzymatic 'combustion': the microbial degradation of lignin. Annual Review of Microbiology 41, 465-505.

Kojima, Y., Tsukuda, Y., Kawai, Y., Tsukamoto, A., Sugiura, J., SAKAINO, M. \& KITA, Y. (1990). Cloning, sequence analysis, and expression of ligninolytic phenoloxidase genes of the white-rot basidiomycete Coriolus hirsutus. Journal of Biological Chemistry 265, 15224-15230.

LONBERG, N. \& GILBERT, W. (1985). Intron/exon structure of the chicken pyruvate kinase gene. Cell 40, 81-90.

MalKIN, R. \& MalmströM, B. G. (1970). The state and function of copper in biological systems. Advances in Enzymology 33, 177-244.

VAN DER MEER, R. (1989). Methods for the search of quinoproteins. PhD thesis, University of Technology Delft, The Netherlands.

VAN Der MEer, R. A., VAN WassenaAR, P. D., VAN BrouWERShaven, J. H. \& DuINE, J. A. (1988). Primary structure of a PQQ containing peptide from porcine kidney diamine oxidase. In $P Q Q$ and Quinoproteins, pp. 348-350. Edited by J. A. Jongejan \& J. A. Duine. Dordrecht, Boston \& London: Kluver Academic Publishers.
Messerschmidt, A. \& Huber, R. (1990). The blue oxidases, ascorbate oxidase, laccase and ceruloplasmin. European Journal of Biochemistry 187, 341-352.

Messerschmidt, A., Rossi, A., Ladenstein, R., Huber, R., BologNesi, M., Gatti, G., Marchesini, A., Petruzelli, R. \& FinazziAGRo, A. (1989). X-ray crystal structure of the blue oxidase ascorbate oxidase from zucchini. Journal of Molecular Biology 209, 513-529.

Niku-Paavola, M.-L., Karhunen, E., Salola, P. \& Raunio, V. (1988). Ligninolytic enzymes of the white-rot fungus Phlebia radiata. Biochemical Journal 254, 877-884.

Ohkawa, J., Okada, N., Shimnyo, A. \& Takano, M. (1989). Primary structure of cucumber (Cucumis sativus) ascorbate oxidase deduced from cDNA sequence: homology with blue copper proteins and tissue-specific expression. Proceedings of the National Academy of Sciences of the United States of America 86, 1239-1243.

Ortel, T. L., Takahashi, N. \& Putnam, F. W. (1984). Structural model of human ceruloplasmin based on internal triplication, hydrophilic/hydrophobic character, and secondary structure domains. Proceedings of the National Academy of Sciences of the United States of America 81, 4761-4765.

Pelham, H. R. B. (1982). A regulatory upstream promoter element in the Drosophila Hsp70 heat shock gene. Cell 30, 517-528.

Pribnow, D., Mayfield, M. B., Nipper, V. J., Brown, J. A. \& Gold, M. H. (1989). Characterization of a cDNA encoding a manganese peroxidase, from the lignin-degrading basidiomycete Phanerochaete chrysosporium. Journal of Biological Chemistry 264, 5036-5040.

RAEDER, U. \& BRODA, P. (1985). Rapid preparation of DNA from filamentous fungi. Letters in Applied Microbiology 1, 17-20.

Saloheimo, M., Barajas, V., Niku-Paavola, M.-L. \& Knowles, J. K. C. (1989). A lignin peroxidase-encoding cDNA from the whiterot fungus Phlebia radiata: characterization and expression in Trichoderma reesei. Gene 85, 343-351.

TIEN, M. \& TU, C. P. D. (1987). Cloning and sequencing of a cDNA for a ligninase from Phanerochaete chrysosporium. Nature, London 326, 520-523, (and Corrigendum: Nature 328, 742).

Young, R. A. \& DAvis R. W. (1983). Yeast polymerase II genes: isolation with antibody probes. Science $222,778-782$. 